\title{
Tundra Bean Goose Anser fabalis rossicus during spring migration in northern Sweden - rare visitor or regular passage migrant?
}

\author{
Tundrasädgåsen Anser fabalis rossicus under vårflyttningen i norra Sverige - en \\ sällsynt gäst eller regelbunden flyttfågel?
}

\author{
THOMAS HEINICKE
}

\begin{abstract}
In spring 2007-2009, I studied the races of staging Bean Geese Anser fabalis in northern Sweden, both in the hand and in the field. In all study periods, the Tundra race rossicus was found quite regularly with greatest numbers near Alvik in the Luleå region. Simultaneous counts revealed a maximum of 2722 individuals in spring 2009 . The predominance of rossicus at Alvik was confirmed by catching in 2009. As large numbers of Bean Geese in early May have been reported from the Alvik area for many years, rossicus should be considered a regular and numerous spring migrant through northern Sweden. The occurrence of rossicus in northern Sweden is linked by
\end{abstract}

ring recoveries to a breeding population in Finnmark, Norway. Birds, ringed during spring staging in mid May at Valdak marshes, and probably breeding in their wider surroundings, are reported yearly from Luleå region in late April/early May. There is also a link to a moulting site of rossicus at Varanger peninsula, Norway. New recoveries of birds, ringed in northern Sweden, at various sites in Finnmark confirm this connection.

Thomas Heinicke,

Gingster Str. 18, D-18573 Samtens, Germany.

thomas.heinicke@gmx.net

\section{Introduction}

The Bean Goose Anser fabalis is a rare breeding bird in northern parts of Scandinavia (e.g. Nilsson et al. 1999, Svensson et al. 1999, Follestad 1994), using special staging areas along the western coast of the Gulf of Bothnia during spring migration (Skyllberg et al. 2003, 2008, 2009). A planned new railway, crossing the major spring staging area in the Ume River Delta, caused concerns because of possible negative impact on the future development of the Swedish Taiga Bean Goose Anser fabalis fabalis breeding population that migrates in a large extent through that area.

These concerns necessitated new scientific interest in the Bean Goose issues in Sweden. Since the mid 2000s, several studies are being conducted on spring staging Taiga Bean Geese at sites along the Gulf of Bothnia (Nilsson et al. 2008). These studies include catching and neck-banding, organised by Leif Nilsson (Lund University) and Adriaan de Jong (University of Agricultural Sciences, Umeå). Since spring 2007, I have joined these catching events. This has given me the opportunity to study the races of staging Bean Geese, both in the hand and in the field.

\section{Material and methods}

\section{Goose catching}

Goose catching was started in the Ume River Delta $\left(63^{\circ} 45^{\prime} \mathrm{N}, 20^{\circ} 17^{\prime} \mathrm{E}\right.$; Skäret field complex) in April 2005. After a break in spring 2006, catching activities were resumed 17-26 April 2007 in the Ume River Delta $\left(63^{\circ} 44^{\prime} \mathrm{N}, 20^{\circ} 16^{\prime} \mathrm{E}\right.$; fields near Stöcke) and at fields near lake Brånsjön (635' $\mathrm{N}$, $\left.19^{\circ} 51^{\prime} \mathrm{E}\right)$. The activities were repeated in both areas 15-30 April 2008. In 2009, catching started in mid April in the Ume River Delta (fields near Stöcke) and continued from 26 April to 3 May in the Alvik area/Luleå region $\left(65^{\circ} 34^{\prime} \mathrm{N}, 21^{\circ} 45^{\prime} \mathrm{E}\right.$; fields near Klubben and Alviksgården). The geese were caught on cereal stubble fields, using cannon net equipment. Every Bean Goose was individually marked with a blue neckband and separated into $f a-$ balis or rossicus. Additionally, 10 birds (8 fabalis, 2 rossicus) were tagged with satellite transmitters between 2007 and 2009. 
For correct race identification, a combination of the following criteria was used: (1) age and sex, (2) measurements of wing, tarsus, bill-head length, culmen and bill structure (see Dzubin \& Cooch 1992), (3) form of the nail (round in fabalis, oval in rossicus), and number of teeth in the upper mandible (20-23 in rossicus, 24-27 in fabalis). Every marked bird was also photographed, and for each goose the bill-colour type after Burgers et al. (1991) was determined from these pictures. For later genetic tests, also feather samples from every goose were collected.

\section{Goose counts}

During the spring season of 2007, 2008 and 2009, I made repeated goose counts in the Ume River Delta and around Lake Brånsjön. In 2008, goose flocks near Djäkneböle (SW of Umeå) were also counted regularly. On 29-30 April 2008, I made my first goose counting trip to staging sites near Skellefteå, Piteå and Luleå. Improved site coverage was achieved in 2009 , with regular counts on the same sites as in 2008, and additional counts on Västerslätten/Umeå, on three additional sites near Skellefteå and around Persöfjärden N of Luleå (Table 1). For a detailed description of the main counting sites see Skyllberg et al. (2008).

Goose counts, with identification of subspecies, were carried out during daytime at feeding sites (cereal fields and grasslands) or during daytimeresting at nearby roosts. I used a 20-60× magnification telescope and followed the identification schemes of Barthel \& Frede (1989), Heinicke (2004) and Heinicke et al. (2005) (Table 2). Because some individuals are difficult to identify, I used group identity and separation of groups of the same subspecies within larger mixed flocks (Huyskens 1986, 1999) as an additional identification criteria.

Table 1. Goose counts during spring 2007 to 2009 at staging areas in Västerbotten (Vb) and Norrbotten (Nb) counties in northern Sweden.

Gåsräkningar på rastplatser i Västerbottens (Vb) och Norrbottens (Nb) län vårarna 2007-2009.

\begin{tabular}{|c|c|c|c|c|c|}
\hline $\begin{array}{l}\text { Counting sites } \\
\text { Räkningsplatser }\end{array}$ & $\begin{array}{l}\text { County } \\
\text { Län }\end{array}$ & $\begin{array}{l}\text { Coord- } \\
\text { inates }\end{array}$ & 2007 & 2008 & 2009 \\
\hline $\begin{array}{l}\text { Ume River Delta } \\
\text { Umeå }\end{array}$ & $\mathrm{Vb}$ & $\begin{array}{l}63^{\circ} 45^{\prime} \mathrm{N} \\
20^{\circ} 16^{\prime} \mathrm{E}\end{array}$ & $17-20,22-26 \mathrm{Apr}$ & $15-18,21-23,25-28 \mathrm{Apr}$ & 17-24, 28-30 Apr, 3 May \\
\hline $\begin{array}{l}\text { Lake Bransjön } \\
\text { Umeå }\end{array}$ & $\mathrm{Vb}$ & $\begin{array}{l}63^{\circ} 54^{\prime} \mathrm{N} \\
19^{\circ} 51^{\prime} \mathrm{E}\end{array}$ & $20-22,24 \mathrm{Apr}$ & $18,20-23,25-28,30 \mathrm{Apr}$ & 19, 22-24, 29 Apr \\
\hline $\begin{array}{l}\text { Djäkneböle } \\
\text { Umeå }\end{array}$ & $\mathrm{Vb}$ & $\begin{array}{l}63^{\circ} 47^{\prime} \mathrm{N} \\
20^{\circ} 04^{\prime} \mathrm{E}\end{array}$ & - & 19, 21-28, $30 \mathrm{Apr}$ & 17, 19-23 Apr \\
\hline $\begin{array}{l}\text { Västerslätten } \\
\text { Umeå }\end{array}$ & $\mathrm{Vb}$ & $\begin{array}{l}63^{\circ} 51^{\prime} \mathrm{E} \\
20^{\circ} 12^{\prime} \mathrm{E}\end{array}$ & - & - & 23-24 Apr \\
\hline $\begin{array}{l}\text { Gärdefjärden } \\
\text { Skellefteå }\end{array}$ & $\mathrm{Vb}$ & $\begin{array}{l}64^{\circ} 23^{\prime} \mathrm{N} \\
21^{\circ} 18^{\prime} \mathrm{E}\end{array}$ & - & - & 25, 28, 30 Apr, 3 May \\
\hline $\begin{array}{l}\text { Innervik } \\
\text { Skellefteå }\end{array}$ & $\mathrm{Vb}$ & $\begin{array}{l}64^{\circ} 42^{\prime} \mathrm{N} \\
21^{\circ} 04^{\prime} \mathrm{E}\end{array}$ & - & - & 25, 28, 30 Apr, 3 May \\
\hline $\begin{array}{l}\text { Kågegården } \\
\text { Skellefteå }\end{array}$ & $\mathrm{Vb}$ & $\begin{array}{l}64^{\circ} 51^{\prime} \mathrm{N} \\
20^{\circ} 56^{\prime} \mathrm{E}\end{array}$ & - & 29-30 Apr & $25,28,30$ Apr, 3 May \\
\hline $\begin{array}{l}\text { Drängsmark } \\
\text { Skellefteå }\end{array}$ & $\mathrm{Vb}$ & $\begin{array}{l}64^{\circ} 54^{\prime} \mathrm{N} \\
20^{\circ} 58^{\prime} \mathrm{E}\end{array}$ & - & - & 25, 28, 30 Apr, 3 May \\
\hline $\begin{array}{l}\text { Ostträsket } \\
\text { Skellefteå }\end{array}$ & $\mathrm{Vb}$ & $\begin{array}{l}64^{\circ} 55^{\prime} \mathrm{N} \\
21^{\circ} 01^{\prime} \mathrm{E}\end{array}$ & - & 29-30 Apr & 25, 28, 30 Apr, 3 May \\
\hline $\begin{array}{l}\text { Öjebyn } \\
\text { Piteå }\end{array}$ & $\mathrm{Nb}$ & $\begin{array}{l}65^{\circ} 22^{\prime} \mathrm{N} \\
21^{\circ} 26^{\prime} \mathrm{E}\end{array}$ & - & $29 \mathrm{Apr}$ & $25,28,30$ Apr, 3 May \\
\hline $\begin{array}{l}\text { Alvik+Ersnäs } \\
\text { Luleå }\end{array}$ & $\mathrm{Nb}$ & $\begin{array}{l}65^{\circ} 34^{\prime} \mathrm{N} \\
21^{\circ} 45^{\prime} \mathrm{E}\end{array}$ & - & 29-30 Apr & 25-28, 30 Apr, 1-3 May \\
\hline $\begin{array}{l}\text { Persöfjärden } \\
\text { Luleå }\end{array}$ & $\mathrm{Nb}$ & $\begin{array}{l}65^{\circ} 47^{\prime} \mathrm{N} \\
22^{\circ} 05^{\prime} \mathrm{E}\end{array}$ & - & - & 27 Apr, 1 May \\
\hline
\end{tabular}


Table 2. Features used for the field identification of Taiga and Tundra Bean Geese.

Karaktärer som användes i fält för att skilja taiga- och tundrasädgäss.

\begin{tabular}{lll}
\hline & Anser fabalis fabalis & Anser fabalis rossicus \\
\hline Size Storlek & Large and stoutly built goose, +/- size & Smaller than fabalis, size between Greater Whitefront \\
& of a Greylag. Stor och kraftigt byggd & and Greylag, very similar to Pinkfoot. Mindre än \\
& gås, ungefär så stor som grågås. & fabalis, storlek mellan bläsgås och grågås, nästan \\
& & samma som spetsbergsgås.
\end{tabular}

Neck Hals Relatively long, comparatively thin. Relativt lång, jämförelsevis tunn.

Head Huvud Head and upper neck relatively dark collared, lower neck and body paler, flattened and mostly straight billhead-profile. Huvud och övre hals relativt mörkkragad, nedre hals och kropp blekare och vanligen rak näbbhuvud-profil.

Bill Näbb Long and elongated, mostly with dominant orange colour, straight or slightly curved lower mandible. Lång och utdragen, oftast med dominerande orange färg, rak eller något krökt nedre näbbhalva.

Sex Kön

Males larger than females, females similar in size like larger rossicus males. Hanar större än honor, honor stora som stora rossicus.

Voice Läte Calls with very low frequency, deeper than Greylag. Läten lågfrekventa, djupare än hos grågås.

Flight Flykt Large-winged, long- and thin-necked goose, often also long bill obvious. Långvingad, lång-och smalhalsad, ofta påtaglist lång näbb.
Relatively short, comparatively thick. Relativt kort, jämförelsevis tjock.

Head mostly darker brownish-grey, but neck and body paler, body colour often more grey-brownish, roundish head profile. Huvud oftast mörkare brungrått, men hals och kropp blekare, kroppsfärg ofta mera gråbrun, rundad huvudprofil.

Mostly short, robust and very compact, mostly dominantly dark with orange bill ring (dominantly orange bill rare), clearly to slightly curved lower mandible, large males sometimes show quite long bills. Oftast kort, robust och mycket kompakt, oftast dominerande mörk med orange näbbring (dominerande orange näbb sällsynt), tydligt till något krökt nedre näbbhalva, stora hanar ibland med tämligen lång näbb.

Males larger than females, larger males in size like fabalis females. Hanar större än honor, stora hanar som fabalis-honor

Calls with much higher frequency than fabalis, higher than Greylag. Läten med mycket högre frekvens än hos fabalis, högre än hos grågås.

Shorter and broader wings, short and thick-necked, dark and roundish head quite obvious. Kortare och bredare vingar, kort- och tjockhalsad, mörkt och rundat huvud tydligt.

\section{Results}

\section{Goose catching and measurements}

In 2005-2009, 74 Bean geese were caught and neckbanded. Thirty (41\%) of the birds belonged to the subspecies $A$.f. rossicus. Of the birds caught in the Ume River Delta $97 \%$ were A.f. fabalis, but in the Alvik area only $22 \%$ belonged to this subspecies (Table 3).

To demonstrate correct identification of the ringed rossicus birds, statistics for some important measurements are shown in Table 4 (for detailed measurements see Appendix 1). As many secondyear birds are still not fully grown in spring, only measurements for adult birds were used. The measurements of the Tundra Bean Geese caught in 2009 fit well within the range of measurements given for A. f. rossicus in Cramp (1977; Table 5). The grinning patch was even more prominent than the data in this source. Also, the percentages of bill-colour 
Table 3. Number of Bean geese caught at different spring staging areas in northern Sweden.

Antal gäss som fångades på olika vårrastplatser för sädgås i norra Sverige.

\begin{tabular}{lcccccc}
\hline Subpecies & $\begin{array}{c}2005 \\
\text { Ume Delta }\end{array}$ & $\begin{array}{c}2007 \\
\text { Brånsjön }\end{array}$ & $\begin{array}{c}2008 \\
\text { Ume Delta }\end{array}$ & $\begin{array}{c}2009 \\
\text { Ume Delta }\end{array}$ & $\begin{array}{c}2009 \\
\text { Alvik/Luleå }\end{array}$ & Total \\
\hline Anser fabalis fabalis & 4 & 1 & 27 & 4 & 8 & 44 \\
Anser fabalis rossicus & 0 & 0 & 0 & 1 & 29 & 30 \\
\hline
\end{tabular}

Table 4. Measurements of adult Tundra Bean Geese A. f. rossicus caught in spring 2009 in northern Sweden. Measurements in millimetres.

Mätningar av adulta tundrasädgäss A. f. rossicus fångade våren 2009 i norra Sverige. Mått i millimeter.

\begin{tabular}{lrrrrr}
\hline Measurements Mått & Min & Max & Mean & SD & N \\
\hline wing length adult males vinglängd adulta hanar & 404 & 456 & 437.9 & 13.97 & 15 \\
wing length adult females vinglängd adulta honor & 393 & 436 & 416.0 & 14.06 & 13 \\
culmen length adult males kulmen adulta hanar & 57.2 & 62.0 & 59.5 & 1.57 & 15 \\
culmen length adult females kulmen adulta honor & 51.1 & 57.9 & 54.2 & 2.22 & 13 \\
bill-head length adult males näbblängd adulta hanar & 116 & 123 & 120.5 & 1.67 & 15 \\
bill-head length adult females näbblängd adulta honor & 105 & 114 & 111.0 & 3.28 & 13 \\
bill depth adult males näbbhöjd adulta hanar & 30.9 & 33.4 & 32.0 & 0.65 & 12 \\
bill depth adult females näbbhöjd adulta honor & 28.7 & 31.4 & 29.8 & 0.79 & 12 \\
tarsus adult males tars adulta hanar & 74.8 & 81.3 & 78.6 & 1.84 & 12 \\
tarsus adult female tars adulta honor & 71.0 & 77.5 & 73.7 & 2.15 & 12 \\
grinning patch adult males näbbglipa adulta hanar & 8.9 & 10.2 & 9.4 & 0.38 & 12 \\
grinning patch adult females näbbglipa adulta honor & 8.5 & 9.5 & 8.9 & 0.30 & 12 \\
\hline
\end{tabular}

Table 5. Comparison of measurements of Tundra Bean Geese from northern Sweden with literature data from rossicus and fabalis: min-max span, means in brackets.

Jämförelse av mått för tundrasädgås från norra Sverige och mått från litteraturen för rossicus och fabalis: min-max-intervall, medelvärde i parentes.

\begin{tabular}{lcccccc}
\hline & \multicolumn{2}{c}{ rossicus (this study) } & \multicolumn{2}{c}{ rossicus (Cramp 1977) } & \multicolumn{2}{c}{ fabalis (Cramp 1977) } \\
& adult male & adult female & adult male & adult female & adult male & adult female \\
\hline $\begin{array}{l}\text { Wing } \\
\text { Vinge }\end{array}$ & $404-456(438)$ & $393-436(416)$ & $430-478(454)$ & $405-458(433)$ & $452-520(481)$ & $434-488(460)$ \\
$\begin{array}{l}\text { Culmen } \\
\text { Kulmen }\end{array}$ & $57-62(59.5)$ & $51-58(54.2)$ & $52-63(57.7)$ & $49-60(54.6)$ & $57-70(63.6)$ & $55-66(60.0)$ \\
$\begin{array}{l}\text { Tarsus } \\
\text { Tars } \\
\text { Grinning patch }\end{array}$ & $75-81(78.6)$ & $71-78(73.7)$ & $70-81(75.2)$ & $69-79(73.9)$ & $76-90(82.2)$ & $73-80(76.6)$ \\
Näbbglipa & $8.9-10.2(9.4)$ & $8.5-8.5(8.9)$ & $7.0-10.0(7.9)$ & $6.9-8.6(7.5)$ & $5.5-7.3(6.4)$ & $5.3-7.0(6.2)$ \\
\hline
\end{tabular}

types of the rossicus birds in our sample were very similar to those of birds ringed in the Netherlands (type $2 \mathrm{~b}=3,3 \%, 2 \mathrm{c}=40,0 \%, 2 \mathrm{~d}=56,7 \% ; \mathrm{n}=30$; Burgers et al. 1991).

\section{Goose counts}

During the goose counts, staging Tundra Bean Geese were found at all visited sites (Table 6). By far the largest numbers were found in the Alvik-Er- snäs area SW of Luleå. This area appears to be the key staging area for A.f. rossicus in Northern Sweden. In most sites, maximum numbers occurred in late April or early May, when most Taiga Bean Geese have departed already. A flock of 211 rossicus Bean Geese observed near Lake Brånsjön on 20 April 2007 was probably exceptional (early occurrence and high number for this site). They may have been forced to stop over by heavy snowfall and stayed only for one day. 
Table 6. Maximum counts (with counting dates in brackets) of Tundra Bean Geese at different sites during spring migration 2007-2009 in northern Sweden.

Högsta antal (med räkningsdatum i parentes) tundrasädgäss på olika platser vårarna 2007-2009 i norra Sverige.

\begin{tabular}{lccc}
\hline Site & 2007 & 2008 & 2009 \\
\hline Ume River Delta & $32(19 \mathrm{Apr})$ & $57(22 \mathrm{Apr})$ & $291(29 \mathrm{Apr})$ \\
Brånsjön & $211(20 \mathrm{Apr})$ & $30(26 \mathrm{Apr})$ & $60(29 \mathrm{Apr})$ \\
Djäkneböle & - & $42(25 \mathrm{Apr})$ & 0 \\
Västerslätten & - & - & $65(24 \mathrm{Apr})$ \\
Gärdefjärden & - & - & $116(03 \mathrm{May})$ \\
Innervik & - & - & $38(28 \mathrm{Apr})$ \\
Kågegården & - & $79(29 \mathrm{Apr})$ & $128(28 \mathrm{Apr})$ \\
Dränsmark & - & - & $20(28 \mathrm{Apr})$ \\
Osträsket & - & $191(29 \mathrm{Apr})$ & $356(30 \mathrm{Apr})$ \\
Piteå & - & $39(29 \mathrm{Apr})$ & $118(28 \mathrm{Apr})$ \\
Alvik+Ersnäs & - & $1360(29 \mathrm{Apr})$ & $2457(02 \mathrm{May})$ \\
Persöfjärden & - & - & $8(01 \mathrm{May})$ \\
\hline
\end{tabular}

Table 7. Simultaneous counts of staging Tundra Bean Geese at different sites during spring migration 2009 in northern Sweden.

Samtidiga räkningar av rastande tundrasädgäss på olika platser under vårflyttningen 2009 i norra Sverige.

\begin{tabular}{lrrrrrrrr}
\hline Site & \multicolumn{2}{c}{$24+25$ April } & \multicolumn{2}{c}{$27+28$ April } & \multicolumn{2}{c}{$29+30$ April } & \multicolumn{2}{c}{$2+3$ May } \\
& rossicus & fabalis & rossicus & fabalis & rossicus & fabalis & rossicus & fabalis \\
\hline Ume River Delta & 82 & 1024 & 150 & $>450$ & 291 & 397 & 1 & 0 \\
Brånsjön & 27 & 1024 & $?$ & $?$ & 60 & 451 & $?$ & $?$ \\
Västerslätten & 65 & 112 & $?$ & $?$ & 0 & 0 & 0 & 0 \\
Gärdefjärden & 0 & 111 & 0 & 39 & 0 & 154 & 116 & 3 \\
Innervik & 0 & 69 & 38 & 0 & 6 & 0 & 0 & 0 \\
Kågegården & 3 & 17 & 128 & 68 & 0 & 12 & 0 & 0 \\
Dränsmark & 8 & 190 & 20 & 50 & 0 & 0 & 0 & 0 \\
Osträsket & 0 & 114 & 219 & 97 & 356 & 176 & 30 & 0 \\
Piteå & 75 & 41 & 118 & 0 & 94 & 0 & 5 & 0 \\
Alvik+Ersnäs & 754 & 500 & 1480 & 379 & 1907 & 258 & 2457 & 44 \\
Persöfjärden & $?$ & $?$ & 3 & 47 & 8 & 155 & $?$ & $?$ \\
\hline Total & 1014 & 3202 & 2156 & $(>788)$ & 2722 & 1603 & 2609 & $>47$ \\
\hline
\end{tabular}

In 2009, numbers of staging Tundra Bean Geese increased quickly during the last days of April (Table 7). Numbers culminated by the end of April and early May, with the highest concentration in a single site on 2 May (Alvik). Numbers of Tundra Bean Geese were fluctuating strongly in the Alvik/ Ersnäs area (27 Apr: 1540, 28 Apr: 1440, 30 Apr: 1907, 1 May: 1300, 2 May: 2457, 3 May: 1650). This indicates high migration activity and a high turnover rate during this period. Taiga Bean Goose numbers, on the other hand, dropped markedly dur- ing the last days of April, and, by early May, most birds had departed. Therefore, the vast majority of Bean Geese at the coastal staging areas in early May were of the subspecies rossicus.

\section{Recoveries of marked birds}

Two neckbanded Tundra Bean Geese were observed in the Alvik area in 2008. One of them was also observed there in 2009. The birds had been marked at the spring staging area "Valdak marshes" 
$\left(70^{\circ} 10^{\prime} \mathrm{N}, 24^{\circ} 50^{\prime} \mathrm{E}\right)$ along the Porsangen Fjord, Northern Norway (one in May 2003 and the other in May 2005). Subspecies identification of these birds as rossicus was verified by measurements and genetics (Aarvak \& Øien 2005, T. Aarvak pers. comm.). After their visits in Northern Sweden in 2008 and 2009, the birds were also observed at the Valdak marshes in mid May the same year (Aarvak \& Øien 2009, T. Aarvak pers. comm.).

A Swedish marked rossicus bird, ringed on 19 April 2009 at Ume River Delta, was observed there until 29 April. Afterwards it went to the Alvik/Ersnäs area SW of Luleå, where it was seen on 1-3 May and finally on 5 May 2009 at Persöfjärden north of Luleå.

Additionally, one of the Swedish rossicus neckbands was found near a coastal spring staging area of Tundra Bean Geese on Varanger peninsula in the second half of May, whereas two other birds, one with a transmitter, were observed in late May at the Tana river basin north-east of Utsjoki along the Norwegian-Finnish border. This transmitter birds was located in late May in a nearby tundralike habitat in Finland. The second transmitter bird was located during the breeding season also in a tundra-like habitat in the central part of the Norwegian Finnmark (L. Nilsson in litt.).

In late July 2009, five different Swedish rossicus with neckbands were observed at a moulting site of Tundra Bean Geese in central Varanger peninsula (I. Øien, T. Aarvak in litt.).

\section{Discussion}

\section{Status of the Tundra Bean Goose in northern Sweden}

The occurrence of large numbers of Tundra Bean Geese in northern Sweden was completely unknown before the study reported here. SOF (2002) characterizes rossicus only as a migrant through central and southern Sweden, and with insufficient knowledge of numbers of birds involved. Persson (1997) reported up to 500 birds during autumn migration in Skåne, the highest number of rossicus ever in Sweden so far.

For Västerbotten, Olsson \& Wiklund (1999) listed only two observations of single birds: 3 May 1995 at lake Brånsjön and 9 November 1996 at Röbäcksslätten near Umeå. Also Skyllberg et al. (2003, 2008 \& 2009) routinely assumed almost all spring staging Bean Geese in northern Sweden to belong to the ssp. fabalis. Skyllberg et al. (2008) mentioned spring observations of four Norwegian marked rossicus neckbands from the Luleå region, but they didn't take into account that a certain part of spring staging Bean Geese in northern Sweden could be of the rossicus subspecies.

Only quite recently, Skyllberg et al. (2009) reported, that up to 50 Tundra Bean Geese may use staging areas in southern Västerbotten, but explain this as a result of deviation from their normal flyway to Kola peninsula. They also considered the possibility, due to 500-1000 Tundra Bean Geese moulting in Finnmark (Aarvak \& Øien 2009), and regular occurrence of neckbanded birds from Finnmark in the Luleå region, that a substantial number of Bean Geese counted in Alvik/Ersnäs and Persöfjärden could be of the rossicus subspecies.

Unfortunately, Skyllberg et al. (2009) do not give any exact figures for the numbers of rossicus involved, but suggested that the higher numbers of Bean Geese they counted in Northern Sweden in 2007-2008 versus the period 2002-2006 could be a result of a "contribution" from rossicus birds. However, using their numbers of maximum counts for Västerbotten and Norrbotten (see Skyllberg et al. 2009), this would give a contribution of about 500 birds only. Compared to a minimum of 1669 and 2722 Tundra Bean Geese counted in Northern Sweden in 2008 and 2009 respectively (Tables 6 \& 7), their estimate of up to 500 rossicus birds is by far too low.

Looking at the phenology of spring-staging Tundra Bean Geese in 2009 (Table 7), their numbers peak during the last days of April and in early May. This means that the migration peak is $1-2$ weeks later than for Taiga Bean Geese. This also means, that a final wave of Bean Geese staging in the Ume River Delta late in the migration period (early May), assumed to be Taiga Bean Geese by Skyll-

Table 8. Maximum counts of Bean Geese in Alvik/ Ersnäs area during spring 2002-2008.

Högsta antal räknade sädgäss i Alvik/Ersnäs-området vårarna 2001-2008.

\begin{tabular}{lll}
\hline Year & \multicolumn{2}{l}{ Maximum count Source } \\
Ar & Högsta räknat & Källa \\
\hline 2002 & $823(28$ Apr) & Skyllberg et al. (2008) \\
2003 & $817(27$ Apr) & Skyllberg et al. (2008) \\
2004 & $1230(1 \mathrm{May})$ & Sjöberg \& de Jong (2005) \\
2005 & $2127(4 \mathrm{May})$ & Sjöberg \& de Jong (2005) \\
2006 & $1230(3 \mathrm{May})$ & Skyllberg et al. (2008) \\
2007 & $1160(26 \mathrm{Apr})$ & Sjöberg \& de Jong (2007) \\
2008 & $2022(30 \mathrm{Apr})$ & Sjöberg \& de Jong (2008) \\
\hline
\end{tabular}


Table 9. Reports of larger flocks of resting Bean Geese in southern Sweden in early May 2008 and 2009 (source: SVALAN Rapportsystemet för fåglar).

Rapporter om större flockar av rastande sädgäss i södra Sverige i början av maj 2008 och 2009 (källa: SVALAN Rapportsystemet för fåglar).

\begin{tabular}{llcclc}
\hline 2008 & Place & Numbers & 2009 & Place & Pumbers \\
& Plats & Antal & & Plats & Antal \\
\hline 1 May & Tåkern & 400 & 1-2 May & Östen & 600 \\
2 May & Kvismaren & 550 & 1 May & Kvismaren & 200 \\
3 May & Kvismaren & 400 & 3 May & Kvismaren & 200 \\
4 May & Tåkern & 200 & 3 May & Tåkern & 130 \\
4 May & Kvismaren & 100 & & & \\
\hline
\end{tabular}

berg et al. (2008, 2009), consists in fact mostly of Tundra Bean Geese.

These differences in timing of spring migration between Tundra and Taiga Bean Geese in Northern Sweden can be used, when interpreting count data from the Alvik-Ersnäs area from previous years. As maximum numbers in the Luleå region between years 2002 and 2008 were always counted in the last days of April or in early May (Table 8), this time frame strongly indicates that at least since 2002 a high proportion of rossicus birds is involved in spring-staging Bean Goose numbers there.

In this context, substantial numbers of staging Bean Geese in Central Sweden in early May in 2008 and 2009 are of special interest (Table 9 and SVALAN). Although no information on subspecies was given for most of these observations, the late timing makes these birds good candidates for Tundra Bean Geese, which, thus, should be added to the numbers of rossicus observed in Northern Sweden at the same time. Taiga Bean Geese at spring staging areas in southern Ostrobothnia (Kristinestad and Kauhajoki/Finland), which mainly use staging areas in Central Sweden before, have their migration peak even 1-2 weeks earlier than in southern Västerbotten (Skyllberg et al. 2009). This fact and also the recoveries of two Norwegian rossicus neckbands, observed in Kvismaren on 19 April 2006 and 17 March 2007 respectively (Aarvak \& Øien 2009) support the opinion of more rossicus birds staging in Central Sweden in late April/ early May.

\section{Breeding range of Tundra Bean Geese migrating through northern Sweden}

A number of neckband recoveries from Norwegian and Swedish Tundra Bean Geese and data from

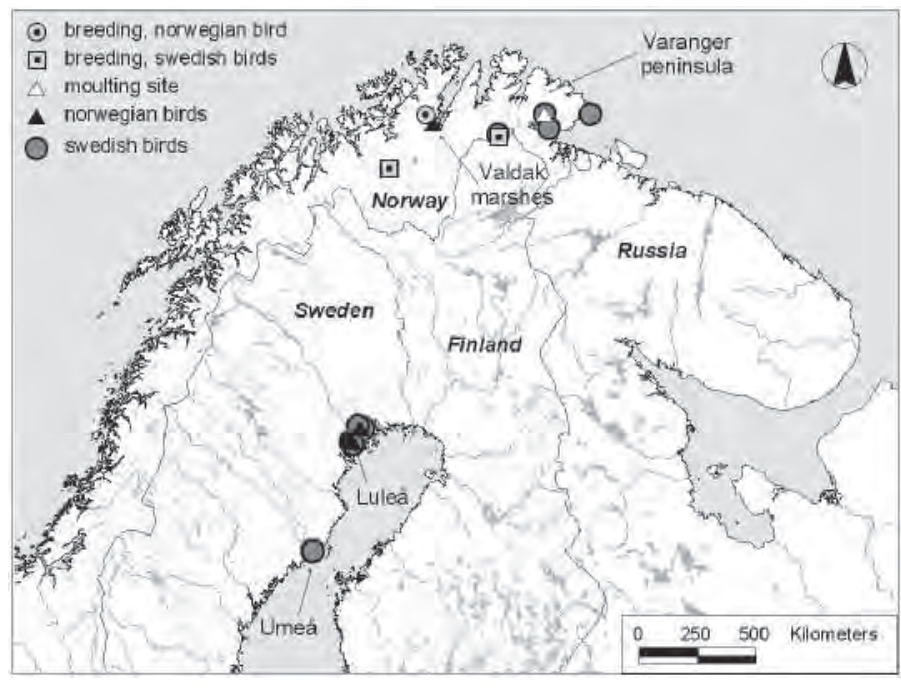

Figure 1. Connectivity between spring staging areas of Tundra Bean Geese in northern Sweden $($ grey circles $=$ Swedish neckbands, black triangle $=$ Norwegian neckbands) and staging, moulting and breeding areas in northern Scandinavia revealed by ring recoveries and satellite telemetry (for details see text).

Samhörigheten mellan vårrastplatser för tundrasädgås $i$ norra Sverige (grå cirklar $=$ svenska halsringar, svarta trianglar = norska halsringar) och rast-, ruggnings- och häckningsplatser $i$ norra Skandinavien så som de framgår av återfynd och satellittelemetri (se texten för detaljer). 
two Swedish transmitter rossicus birds are now available to link the staging sites along in Northern Sweden with the breeding area of Tundra Bean Geese (Figure 1). Four out of eight neckbanded rossicus, caught in mid May at Valdak marshes in Northern Norway (Aarvak \& Øien 2005, 2006 \& 2009, Øien \& Aarvak 2007), were later observed in the Luleå region between late April and early May. Annual arrival in Valdak was between 10 and 14 May, sometimes only 4 days after they were last seen near Luleå (Aarvak \& Øien 2009). One rossicus bird, caught in mid May 2006 at Valdak Marshes, and fitted with a satellite transmitter, was located during breeding time in tundra habitat west of the Porsangerfjord, but, due to failed breeding, the bird later on went to central Varanger peninsula for moult, where also two of the birds, seen in Northern Sweden, were observed (Aarvak \& Øien 2006, 2009).

As the Valdak marshes only host smaller numbers of staging Tundra Bean Geese in May (maximum: 216 birds in 2008; Aarvak \& Øien 2009), there should exist other spring-staging areas in Finnmark or in neighbouring parts of Finland and Russia. At least two such areas have been confirmed by recoveries of Swedish Tundra Bean Geese in Northern Norway: Kariel/Varanger peninsula $\left(70^{\circ} 06^{\prime} \mathrm{N}\right.$, $29^{\circ} 23^{\prime}$ E) and Tana River near Sirma $\left(70^{\circ} 01^{\prime} \mathrm{N}\right.$, $\left.27^{\circ} 25^{\prime} \mathrm{E}\right)$.

During the breeding season, two rossicus birds, fitted with satellite transmitters near Luleå, were recorded in tundra-like habitats in northernmost Finnish Lapland and Norwegian Finnmark respectively. Aarvak \& Øien (2009) reported breeding of rossicus birds in tundra-like habitats in central part of the Norwegian Finnmark, and stated, that the breeding range of Taiga Bean Geese in Finnmark County is restricted to its easternmost, forested parts. There is no reason to expect rossicus birds, that breed east of the Kola Peninsula, to pass northern Sweden. Thus, the breeding range of the rossicus birds staging in Northern Sweden consists of tundra-like habitats in Norwegian Finnmark, Northern Finnish Lapland and, maybe Kola Peninsula in Russia.

The Norwegian breeding bird atlas (Gjershaug et al. 1994) presents breeding records of Bean Geese in areas, now known to be within the breeding range of Tundra Bean Geese. This atlas is based on observations from 1977-1986, and, unless a major shift in breeding habitat choice of Taiga Bean Geese has occurred, the Bean Geese of tundra-like habitats were Tundra Bean Geese even then. These birds were likely to use the same migration route as they do today, and, consequently, were almost entirely overlooked by birdwatchers in Northern Sweden.

Consequences for the size estimate of the northern Scandinavian Bean Goose population

Based on the assumption that all Bean Geese migrating through Northern Sweden belonged to the fabalis ssp., Skyllberg et al. (2008 \& 2009) estimated the current breeding population of Taiga Bean Geese in Northern Scandinavia at 5000-6000 birds. This study shows that this estimate is poorly founded, because a substantial proportion of these birds are Tundra Bean Geese. This is particularly true for the Bean Geese staging near Luleå, which contributed with about one-third of their estimate.

Skyllberg et al. $(2008,2009)$ also assumed that all Scandinavian Taiga Bean Geese migrate along the coast of Northern Sweden, and that all these migrants breed in Scandinavia. There is no support for these assumptions. Instead, data from satellite transmitters fitted on Taiga Bean Geese in the Ume River Delta falsify the latter assumption. Some birds were heading for breeding areas in Finland and northern Karelia in Russia (L. Nilsson, pers. comm.).

The conclusion is that the estimates of the Scandinavian Taiga Bean Goose population made by Skyllberg et al. are based on faulty assumptions. Given the proportion of Tundra Bean Geese and a number of outside-Scandinavia-breeders among spring-staging Bean Geese along the coast of Northern Sweden, the Scandinavian population of Taiga Bean Geese is probably much smaller than 5000-6000 individuals. The number of Taiga Bean Geese that use other, more westerly migration routes is probably not large enough to compensate for the other effects. A devaluation of the Scandinavian breeding population calls for further investigations and stronger conservation measures for this species, which already is categorized as Near-Threatened in Sweden (Gärdenfors 2005) and Vulnerable in Norway (Gjershaug et al. 2006).

Finally, it must be stressed, that Bean Geese in Sweden no longer can be assumed, routinely(!) to be Taiga Bean Geese. Neckband sightings and (unpublished) counts have shown that fair numbers of Tundra Bean Geese occur in Sweden also during autumn migration and in winter. Improved classification of Bean Geese to subspecies is badly needed, because first when a large proportion of Bean Geese is classified at the subspecies level, can the true population size of both subspecies in Sweden 
and its neighbouring countries be measured satisfactory.

\section{Acknowledgements}

I'm extremely grateful to many people who kindly helped with goose catching, especially Adriaan de Jong, Leif Nilsson, Kjell Sjöberg, Hakån Tyren, Kees Polderdijk and Rolf Gustafsson. In particular, I thank Adriaan de Jong for his great hospitality and organisational help during my stays in Northern Sweden, but also for his help and discussions in improving the manuscript. Financial support for this study was provided by Stiftelsen Naturvård vid Nedre Umeälven (through grants to prof. Kjell Sjöberg, Swedish University of Agricultural Sciences).

\section{References}

Aarvak, T. \& Øien, I.J. 2005. Overvåking av saedgås i Norge $i$ 2005. Norsk Ornitologisk Forening. NOF rapport 3-2005.

Aarvak, T. \& Øien, I.J. 2006. Overvåking av scedgås $i$ Norge $i$ 2006. Norsk Ornitologisk Forening. NOF rapport 5-2006.

Aarvak, T. \& Øien, I.J. 2009. Monitoring of Bean Goose in Finnmark County, Norway - results from 2008. Norsk Ornitologisk Forening. NOF rapport 2-2009.

Barthel, P.H. \& Frede, M. 1989. Die Bestimmung von Gänsen der Gattung Anser. Limicola 3: 1-31.

Burgers, J., Smit, J. J. \& van der Voet, H. 1991. Origins and systematics of two types of the Bean Goose Anser fabalis (Latham, 1787) wintering in the Netherlands. Ardea 79: 307-315.

Cramp, S. 1977. Handbook of the birds of Europe, the Middle East and North Africa. Vol. 1: Ostrich to Ducks. Oxford University Press. Oxford, London and New York.

Dzubin, A. \& Cooch, E. 1992. Measurements of Geese: General Field Methods. California Waterfowl Association. Sacramento, California.

Follestad, A. 1994. Sædgås Anser fabalis. In: Gjershaug, J.O., Thingstad, P.G., Eldøy, S. \& Byrkjeland, S. (eds.). Norsk fugleatlas. Norsk Ornitologisk Forening, Klæbu.

Gärdenfors, U. (ed.) 2005. Rödlistade arter i Sverige 2005 - The 2005 Red List of Swedish Species. ArtDatabanken, SLU, Uppsala.

Gjershaug, J.O., Thingstad, P.G., Eldøy, S. \& Byrkjeland, S. 1994. Norsk fugleatlas. Norsk Ornitologisk Forening, Klæbu.

Gjershaug, J.O., Kålås, J.A., Lifjeld, J., Strann, K.-B., Strøm, H. \& Thingstad, P.G. 2006. Aves. In: Kålås, J.A., Viken, Å. \& Bakken, T. (eds.). Norsk Rødliste 2006 - 2006 Norwegian Red List. Artsdatabanken, Norway.

Heinicke, T. 2004. Neue Erkenntnisse zum Auftreten der Waldsaatgans in Mecklenburg-Vorpommern. Ornithol.
Rundbr. Mecklenburg-Vorp. 45: 3-18.

Heinicke, T., Mooij, J. \& Steudtner, J. 2005. Zur Bestimmung von Saatgans (Anser f. fabalis, A. f. rossicus) und Kurzschnabelgans (Anser brachyrhynchus) und deren Auftreten in Ostdeutschland. Mitt. Ver. Sächs. Ornithol. 9: 533-553.

Huyskens, G. P. R. 1986. Het Europese Rietganzenprobleem Anser fabalis. Oriolus 52: 105-256.

Huyskens, G. P. R. 1999. Die Taigasaatgans (Anser fabalis): eine Art die dringend weltweit geschützt werden soll. Unpublished Manuscript.

Nilsson, L., van den Bergh, L. \& Madsen, J. 1999. Taiga Bean Goose Anser fabalis fabalis. - In: Madsen, J., Cracknell, G.S. \& Fox, A.D. (eds.). Goose populations of the Western Palearctic. A review of status and distribution. Wetlands International Publ. No. 48. Wetlands International, Wageningen, The Netherlands. National Environmental Research Institute, Rönde, Denmark.

Nilsson, L., de Jong, A. \& Sjöberg, K. 2008. De svenska

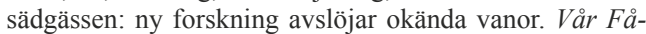
gelvärld 67: 6-10.

Olsson, C. \& Wiklund, J. 1999. Västerbottens fåglar. Västerbottens Ornitologiska Förening. Umeå.

Øien, I.J. \& Aarvak, T. 2007. Overvåking av dverggås og sadgås $i$ Norge $i$ 2007. Norsk Ornitologisk Forening. NOF rapport 6-2007.

Persson, H. 1997. Tundrasädgåsen Anser serrirostris rossicus i Skåne 1974-1996. Anser 36:179-184.

Sjöberg, K. \& de Jong, A. 2005. Fågelstudier 2005 med anledning av Botniabanansdragning över Umeälvens mynningsområde. Rapport till Banverket, unpublished.

Sjöberg, K. \& de Jong, A. 2007. Fågelstudier 2007 med anledning av Botniabanansdragning över Umeälvens mynningsområde. Rapport till Banverket, unpublished.

Sjöberg, K. \& de Jong, A. 2008. Fågelstudier 2008 med anledning av Botniabanansdragning över Umeälvens mynningsområde. Rapport till Stiftelsen Naturvård vid Nedre Umeälven, unpublished.

Skyllberg, U., Hansson, P., Bernhardtson, P. \& Naudot, E. 2003. Taigasädgåsen (Anser $f$. fabalis) i Umedeltat och Norra Norrlands kustland - rastantal under våren 20022003 i perspektiv till uppgifter från 70-, 80-, och 90-talen. Fåglar $i$ Västerbotten 28: 54-64.

Skyllberg, U., Hansson, P., Andersson, Ö., Bernhardtson, P., Gustafsson, R., Laisfeldt, M., Naudot, E. \& Nordlund, M. 2008. Spring staging, flyways and population estimate of the northern Scandinavian Taiga Bean Goose (Anser f. fabalis) in 2002-2006. Vogelwelt 129: 253-262.

Skyllberg, U., Nousiainen, I., Hansson, P., Bernhardtson, P., Andersson, Ö. \& Nordlund, M. 2009. Spring migration of the Taiga Bean Goose Anser f. fabalis along the "Western Flyway" in northern Sweden: numbers in 2003-2008 and timing in comparison with the "Central Flyway" in Finland. Ornis Svecica 19: 199-214.

SOF 2002. Sveriges fåglar. 3:e uppl. Stockholm.

Svensson, S., Svensson, M. \& Tjernberg, M. 1999. Svensk fågelatlas. Vår Fågelvärld, supplement 31, Stockholm. 
Appendix 1. Features and measurements (in mm) of Tundra Bean Geese A. f. rossicus caught in northern Sweden.

Karaktärer och mått ( $\mathrm{i}$ mm) för tundrasädgäss A. f. rossicus fångade i norra Sverige.

\begin{tabular}{|c|c|c|c|c|c|c|c|c|c|c|}
\hline$\overline{\text { No }}$ & $\begin{array}{l}\text { Age } \\
\text { Sex } \\
\text { Alder } \\
\text { Kön }\end{array}$ & $\begin{array}{l}\text { Wing } \\
\text { length } \\
\text { Ving- } \\
\text { längd }\end{array}$ & $\begin{array}{l}\text { Culmen } \\
\text { length } \\
\text { Kulmen- } \\
\text { längd }\end{array}$ & $\begin{array}{l}\text { Bill- } \\
\text { head } \\
\text { length } \\
\text { Näbb- } \\
\text { huvud } \\
\text { längd }\end{array}$ & $\begin{array}{c}\text { Bill } \\
\text { depth } \\
\text { Näbb- } \\
\text { höjd }\end{array}$ & Tarsus & $\begin{array}{c}\text { Näbb- } \\
\text { nagel }\end{array}$ & $\begin{array}{l}\text { No. of } \\
\text { teeth } \\
\text { Antal } \\
\text { tänder }\end{array}$ & $\begin{array}{l}\text { Bill } \\
\text { colour- } \\
\text { type } \\
\text { Näbb } \\
\text { färgtyp }\end{array}$ & $\begin{array}{l}\text { Grinn- } \\
\text { ing } \\
\text { patch } \\
\text { Näbb- } \\
\text { glipa }\end{array}$ \\
\hline 1 & ad F & 425 & 52.1 & 110 & 30.0 & 72.0 & oval & 24 & $2 c$ & 8.7 \\
\hline 2 & $2 y F$ & 408 & 52.3 & 112 & 30.1 & 76.6 & oval & 23 & $2 d$ & 9.4 \\
\hline 3 & ad M & 445 & 58.3 & 120 & 32.0 & 80.3 & oval & 23 & $2 d$ & 9.5 \\
\hline 4 & $\operatorname{ad~F}$ & 430 & 54.4 & 114 & 30.3 & 73.2 & oval & 23 & $2 d$ & 9.1 \\
\hline 5 & ad M & 424 & 57.4 & 121 & 31.9 & 78.1 & oval & 22 & $2 d$ & 9.7 \\
\hline 6 & ad F & 407 & 52.2 & 111 & 30.3 & 72.6 & oval & 21 & $2 \mathrm{c}$ & 8.9 \\
\hline 7 & ad F & 404 & 54.0 & 108 & 29.1 & 71.7 & oval & 21 & $2 d$ & 8.5 \\
\hline 8 & ad M & 443 & 61.1 & 122 & 31.5 & 79.0 & oval & 23 & $2 b$ & 9.5 \\
\hline 9 & $\mathrm{ad} \mathrm{M}$ & 420 & 59.7 & 120 & 32.5 & 74.8 & oval & 22 & $2 d$ & 9.9 \\
\hline 10 & ad M & 450 & 58.4 & 122 & 31.7 & 78.8 & oval & 24 & $2 \mathrm{c}$ & 9.0 \\
\hline 11 & $\mathrm{ad} \mathrm{F}$ & 421 & 56.6 & 111 & 29.6 & 73.3 & oval & 23 & $2 \mathrm{c}$ & 8.9 \\
\hline 12 & ad M & 444 & 58.5 & 119 & 32.0 & 78.0 & oval & 23 & $2 d$ & 9.0 \\
\hline 13 & ad M & 430 & 61.1 & 122 & 31.4 & 80.9 & oval & 23 & $2 \mathrm{c}$ & 9.5 \\
\hline 14 & $\operatorname{ad~F}$ & 396 & 52.3 & 113 & 28.9 & 71.0 & oval & 23 & $2 c$ & 8.6 \\
\hline 15 & $\mathrm{ad} \mathrm{F}$ & 428 & 57.1 & 112 & 31.4 & 76.2 & slightly oval & 23 & $2 d$ & 9.3 \\
\hline 16 & ad F & 417 & 54.8 & 113 & 30.9 & 73.7 & oval & 22 & $2 c$ & 8.5 \\
\hline 17 & ad F & 393 & 51.1 & 105 & 29.6 & 71.1 & oval & 24 & $2 c$ & 9.1 \\
\hline 18 & $\operatorname{ad~F}$ & 398 & 53.6 & 111 & 30.2 & 77.5 & oval & 23 & $2 c$ & 9.5 \\
\hline 19 & ad M & 455 & 57.5 & 121 & 33.0 & 80.1 & oval & 23 & $2 d$ & 10.2 \\
\hline 20 & ad M & 452 & 61.0 & 122 & 32.1 & 76.1 & oval & 24 & $2 d$ & 9.0 \\
\hline 21 & ad M & 404 & 57.2 & 116 & 30.9 & 77.5 & oval & 22 & $2 d$ & 8.9 \\
\hline 22 & ad M & 429 & 62.0 & 119 & 33.4 & 81.3 & oval & 22 & $2 d$ & 9.3 \\
\hline 23 & ad M & 435 & 59.2 & 120 & 31.9 & 78.7 & oval & 22 & $2 d$ & 9.3 \\
\hline 24 & $2 \mathrm{y} \mathrm{M}$ & 390 & 55.1 & 111 & 31.8 & 72.6 & oval & 23 & $2 d$ & 9.4 \\
\hline 25 & ad F & 430 & 56.5 & 117 & 29.1 & 77.1 & oval & 23 & $2 d$ & 8.7 \\
\hline 26 & ad F & 436 & 51.3 & 105 & 28.7 & 74.6 & oval & 23 & $2 c$ & 8.8 \\
\hline 27 & ad M & 444 & 61.4 & 123 & - & - & oval & - & $2 c$ & - \\
\hline 28 & ad F & 423 & 57.9 & 113 & - & - & oval & - & $2 d$ & - \\
\hline 29 & ad M & 438 & 58.7 & 120 & - & - & oval & - & $2 c$ & - \\
\hline 30 & $\mathrm{ad} \mathrm{M}$ & 456 & 60.7 & 121 & - & - & oval & - & $2 \mathrm{~d}$ & - \\
\hline
\end{tabular}

